\title{
The aspirin metabolite, salicylate, inhibits 7,12-dimethylbenz[a]anthracene-DNA adduct formation in breast cancer cells
}

\author{
GIULIANA ABBADESSA ${ }^{1}$, ANGELA SPACCAMIGLIO ${ }^{1}$, MARIA LUISA SARTORI $^{1}$, \\ CARLO NEBBIA $^{2}$, MAURO DACASTO ${ }^{2}$, FRANCESCO DI CARLO ${ }^{1}$ and SILVIA RACCA ${ }^{1}$
}

${ }^{1}$ Dipartimento di Scienze Cliniche e Biologiche, ${ }^{2}$ Dipartimento di Patologia animale, Università di Torino, Torino, Italy

Received November 30, 2005; Accepted January 17, 2006

\begin{abstract}
There is evidence that aspirin and other non-steroidal anti-inflammatory drugs may be protective agents against cancer in the gastrointestinal tract. These effects are particularly well documented for the colon and rectum. Some epidemiological and experimental studies have suggested that aspirin could also be a chemopreventive agent against breast cancer. We investigated the effects of the aspirin metabolite, salicylate (SA), on 7,12-dimethylbenz[a]anthracene (DMBA)-DNA adduct formation as well as on the expression of the enzymes involved in the carcinogen bioactivation pathway, in particular cytochrome P450 1A (CYP1A) and cyclooxygenases (COX-1 and $\mathrm{COX}-2)$. The effects of the test drug were examined in both the human mammary carcinoma cell line, MCF-7, and mammary cells derived from DMBA-induced rat mammary tumours (RMTCs). In this study, we also reported the effects of SA on cell growth and viability in breast cancer cells (BCCs). The results demonstrated that DMBA-DNA adduct formation in both cancer cell lines was inhibited by SA at concentrations of $\geq 2.5 \mathrm{mM}$. CYP1A was undetectable in RMTCs while CYP1A induction by B-naphthoflavone in MCF-7 cells was significantly inhibited by $\mathrm{SA}$ in a concentration-dependent manner. Aspirin did not affect COX-1 expression in either of the BCCs. COX-2 was not detected in MCF-7 cells, but its expression in RMTCs was inhibited by SA treatment, which also significantly reduced BCC growth, but failed to cause cell death by necrosis or apoptosis. These data suggest that inhibition of DMBA-DNA adduct formation may contribute to aspirin breast cancer chemopreventive action and indicate that this drug can act in the first stage of carcinogenesis.
\end{abstract}

Correspondence to: Dr Silvia Racca, Dipartimento di Scienze Cliniche e Biologiche, Università di Torino, Ospedale San Luigi Gonzaga, 10043-Orbassano (TO), Italy

E-mail: silvia.racca@unito.it

Key words: aspirin, breast cancer cells, COX, CYP1A, 7,12dimethylbenzanthracene, DNA adducts

\section{Introduction}

The high prevalence of breast cancer provides a strong rationale for identifying new compounds, both natural and synthetic, for use as cancer chemopreventive agents. There is evidence that a variety of chemicals can inhibit, delay, and/or reverse cancer induced by either environmental insults and/or life-style. Non-steroidal anti-inflammatory drugs (NSAIDs) are among the molecules that have emerged as promising candidates for breast cancer prevention (1). Their chemopreventive action in breast cancer has been suggested in several epidemiological (2-11) and experimental studies (12-18). Different mechanisms have been proposed to explain the antitumourigenic action of NSAIDs, including inhibition of cell proliferation and angiogenesis, stimulation and promotion of apoptosis, and inhibition of cyclooxygenase-2 (COX-2)-mediated inflammation, immunosuppression and enhanced invasiveness (19-31). Many chemical agents with antitumourigenic properties can modify the mutagenic and carcinogenic effects of environmental carcinogens such as 7,12-dimethylbenz[a]anthracene (DMBA). For the initiation stage of carcinogen-induced tumourigenesis, a metabolic activation of the carcinogen to reactive metabolites that bind covalently to DNA is required (32). In particular, DMBA is biotransformed by cytochrome P450s (CYPs) to electrophilic dihydrodiolepoxides leading to DNA modifications, mutagenicity, and carcinogenicity. This may proceed through a primary metabolic step carried out by hepatic metabolism, or through complete metabolic activation in the breast in situ, or a combination of both processes (33). It has been reported that many xenobiotic metabolizing enzymes are expressed in the breast and that cyclooxygenase (COX), also referred to as prostaglandin H-synthase (PGHS), may play an important role in carcinogen bioactivation in this or other extrahepatic tissues (34). A variety of chemopreventive agents have been shown to inhibit the in vivo formation of DMBA-induced DNA adducts in rodent mammary cells (35-44).

The main objective of this study was to investigate the effects of the aspirin metabolite, salycilate (SA), on DMBADNA adduct formation as well as on the expression of the enzymes involved in the carcinogen bioactivation pathway, in particular CYPs and COX. For this purpose we used the human breast cancer cell line, $\mathrm{MCF}-7$, because it derives from 
the mammary epithelium, the target tissue of DMBA, and because carcinogen activation has been well characterized in these cells $(45,46)$. Furthermore, recent studies have demonstrated that MCF-7 cells are similar to normal human mammary epithelial cells with regard to expression and activity of CYP1A1, the principal CYP isoform involved in DMBA bioactivation in the liver (47-49). Since a recent in vivo study has shown that SA inhibited DMBA-induced rat mammary carcinogenesis (50), the same goal was pursued in mammary cells derived from DMBA-induced rat mammary carcinomas (RMTCs). In this work, we also reported the effects of SA on cell growth and viability in breast cancer cells (BCCs).

\section{Materials and methods}

DMBA tumour induction, mammary tumour cell separation and culture. Mammary tumours were induced in 50-day-old outbred female Sprague-Dawley rats (Charles River, Calco, Lecco, Italy) by three intragastric intubation of $1 \mathrm{ml}$ DMBA $(10 \mathrm{mg} / \mathrm{ml}$ in olive oil). All animal procedures were carried out in compliance with the EC Directive 86/609/EEC and with the Italian law regulating experiments on animals. When the tumour mean diameter was approximately $1.5 \mathrm{~cm}$, animals were sacrificed by carotid bleeding under $\mathrm{CO}_{2}$ anaesthesia and tumour tissue was isolated under aseptic conditions to obtain primary cultures of RMTCs $(51,52)$. Tissue was freed from necrotic areas and minced with a scalpel in RPMI-1640 medium supplemented with $5 \%$ antibiotics. The minced tissue was resuspended in the same medium containing $0.3 \%$ collagenase and incubated for $90 \mathrm{~min}$ at $37^{\circ} \mathrm{C}$. Afterwards, the suspension was passed through an 80-mesh sieve to remove undigested masses, washed three times with RPMI-1640 (Sigma-Aldrich, Milano, Italy) supplemented with $10 \%$ foetal bovine serum (FBS, Sigma-Aldrich) and plated into culture dishes for a 90-min period. During this time, many stromal elements adhered to the plastic surfaces, while epithelial and blood cells remained in the supernatants. Remaining stromal and blood cells were then removed and passed through a 270mesh sieve, while the ductal fragments, containing most of the epithelial cells, were trapped on the sieve and then removed from it by reverse flushing after washing. The tumour cells thus prepared were resuspended in RPMI-1640 supplemented with $10 \%$ FBS, $1 \%$ glutamine $200 \mathrm{mM}, 1.6 \%$ antibiotics (5000 units penicillin, $5 \mathrm{mg} / \mathrm{ml}$ streptomycin) and hormones $(0.5 \mu \mathrm{g} / \mathrm{ml}$ insulin, $1 \mu \mathrm{g} / \mathrm{ml}$ prolactin, $1 \mu \mathrm{g} / \mathrm{ml}$ corticosterone $)$ and plated in a $75-\mathrm{cm}^{2} \mathrm{~T}$-flask. Cells were grown until confluence at $37^{\circ} \mathrm{C}$ in an atmosphere of $95 \%$ air, $5 \% \mathrm{CO}_{2}$.

The percentage of epithelial cells in culture was quantized using immunohistochemical and flow cytometric analysis. Immunohistochemical examination revealed positivity for keratin (epithelial cell membrane antigen), and negativity for vimentin (marker of mesenchymal cells). Flow cytometry revealed positivity for keratin, negativity for muscle-specific actin and CD45 (leukocyte common antigen).

MCF-7 cell culture. MCF-7 cells were routinely cultured in RPMI-1640 medium supplemented with $1 \%$ glutamine $200 \mathrm{mM}, 1.6 \%$ antibiotics (5000 units penicillin, $5 \mathrm{mg} / \mathrm{ml}$ streptomycin) and 10\% FBS in an atmosphere of $95 \%$ air, $5 \% \mathrm{CO}_{2}$ at $37^{\circ} \mathrm{C}$.
Effects of SA on DMBA-DNA adduct formation. Confluent cultures of cells in $75-\mathrm{cm}^{2}$ T-flasks were exposed to $0.1 \mu \mathrm{g} / \mathrm{ml}$ purified $\left[\mathrm{G}^{3}{ }^{3} \mathrm{H}\right] 7,12-$ Dimethylbenz[a]anthracene $\left(\left[{ }^{3} \mathrm{H}\right] \mathrm{DMBA}\right.$, $23 \mathrm{Ci} / \mathrm{mmol}$; Amersham Pharmacia Biotech, Cologno Monzese, Italia) in the presence of $2.0,2.5,3.0$ or $5.0 \mathrm{mM} \mathrm{SA}$ (SigmaAldrich) for $24 \mathrm{~h}$. The range of SA concentrations was chosen on account of data reported in literature and in view of the amounts of the drug in plasma during treatment of chronic inflammatory diseases. Before use, $\left[{ }^{3} \mathrm{H}\right] \mathrm{DMBA}$ was cleaned by evaporating the toluene solvent using a nitrogen stream, redissolving the residue in $3 \mathrm{ml}$ of hexane, and extracting the hexane phase 10 times using $2 \mathrm{ml}$ of $0.25 \mathrm{M} \mathrm{NaOH}$ in $40 \%$ ethanol (53). Cells were washed twice with cold $0.1 \mathrm{M}$ phosphate-buffered saline solution (PBS), $\mathrm{pH} 7.4$, trypsinized and pelleted. Nuclei were isolated by incubating the cells for $10 \mathrm{~min}$ on ice in $10 \mathrm{mM}$ Tris- $\mathrm{HCl}(\mathrm{pH} 7.5)$, with $320 \mathrm{mM}$ sucrose, $5.0 \mathrm{mM}$ magnesium chloride and 1\% Triton X-100. The nuclei were pelleted by centrifugation at $800 \mathrm{x}$ g for $10 \mathrm{~min}$ at $4^{\circ} \mathrm{C}$, and this digestion was repeated once (44). Nuclei were then lysed with $10 \mathrm{mM}$ Tris- $\mathrm{HCl}, 400 \mathrm{mM} \mathrm{NaCl}$ and $2.0 \mathrm{mM} \mathrm{Na}{ }_{2}$ EDTA, $\mathrm{pH} \mathrm{8.2,} \mathrm{followed} \mathrm{by} \mathrm{treatment} \mathrm{overnight} \mathrm{at}$ $37^{\circ} \mathrm{C}$ with $0.2 \mathrm{ml}$ of $10 \%$ sodium dodecyl sulphate (SDS) and $0.5 \mathrm{ml}$ of proteinase $\mathrm{K}$ solution ( $1 \mathrm{mg}$ proteinase $\mathrm{K}$ in $1 \% \mathrm{SDS}$ and $2 \mathrm{mM} \mathrm{Na} \mathrm{NaDTA}_{2}$. After digestion was complete, $1 \mathrm{ml}$ of saturated $\mathrm{NaCl}$ (approximately $6 \mathrm{M}$ ) was added to each sample and shaken vigorously for $15 \mathrm{sec}$, followed by centrifugation at $1500 \mathrm{x} \mathrm{g}$ for $15 \mathrm{~min}$ at $4^{\circ} \mathrm{C}$. Genomic DNA was then isolated from supernatant by repeated ethanol precipitation as described by Miller et al (54). Isolated DNA exhibited a $260 / 280$ ratio of $>1.9$. The amount of DNA was measured by spectrophotometry and radioactivity bound to DNA was quantified by liquid scintillation counting in a Packard counter. Results were expressed as fmoles $\left[{ }^{3} \mathrm{H}\right] \mathrm{DMBA} / \mathrm{mg}$ DNA.

Evaluation of SA effects on CYP1A, COX-1 and COX-2 expression and induction by Western blot analysis

Sample preparation. CYP1A: to induce CYP1A expression, cells were incubated for $24 \mathrm{~h}$ in the presence of medium containing $0.1 \%$ dimethyl sulfoxide (DMSO) as vehicle or in the presence of $10 \mu \mathrm{M}$ ß-naphthoflavone (B-NF) or $10 \mu \mathrm{M}$ DMBA, dissolved in DMSO, alone or in association with SA 2.5, 3.0 and $5.0 \mathrm{mM}$. Afterwards, microsomes were isolated as follows: detached cells were washed with PBS and homogenized by sonication at $4^{\circ} \mathrm{C}$ in $20 \mathrm{mM}$ Tris- $\mathrm{HCl}, 1.15 \% \mathrm{KCl}$, $1.0 \mathrm{mM}$ EDTA, $1.0 \mathrm{mM}$ phenylmethylsulfonylfluoride (PMSF), $2.0 \mu \mathrm{g} / \mathrm{ml}$ aprotinin, and $2.0 \mu \mathrm{g} / \mathrm{ml}$ leupeptin. The homogenates were centrifuged for $30 \mathrm{~min}$ at $10,000 \mathrm{x} \mathrm{g}$ at $4^{\circ} \mathrm{C}$ and supernatants were subjected to further centrifugation at $100,000 \mathrm{x} \mathrm{g}$ for $60 \mathrm{~min}$ at $4^{\circ} \mathrm{C}$. The resulting microsomal pellets were resuspended in $10 \mathrm{mM}$ Tris-acetate, $1.0 \mathrm{mM}$ EDTA, and $20 \%$ glycerol and sonicated in order to obtain a homogenous membrane suspension. Protein concentration was determined for each sample using the Lowry assay (55).

COX-1: cells were exposed for $24 \mathrm{~h}$ to $0.1 \%$ DMSO as vehicle, and $1 \mu \mathrm{M}$ DMBA dissolved in DMSO, alone or in association with SA 2.0, 2.5, 3.0 or $5.0 \mathrm{mM}$. After trypsinization and washing in cold PBS, whole-cell lysates were prepared by incubating cells with lysis buffer [50 mM HEPES, $250 \mathrm{mM} \mathrm{NaCl}, 10 \%$ glycerol, 1.0\% Triton X-100, $1.5 \mathrm{mM} \mathrm{MgCl}_{2}, 1.0 \mathrm{mM}$ PMSF, $1.0 \mathrm{mM}$ EGTA, $2.0 \mathrm{mM}$ 
$\mathrm{Na}_{3} \mathrm{VO}_{4}, 10 \mu \mathrm{g} / \mu 1$ aprotinin and $10 \mu \mathrm{g} / \mu 1$ leupeptin] on ice for $1 \mathrm{~h}$ as described by Pham et al (56). Protein estimation was performed using the Bradford method (57).

COX-2: cells were exposed to $0.1 \%$ DMSO, and $1 \mu \mathrm{M}$ DMBA dissolved in DMSO, alone or in the presence of SA 2.5 or $5.0 \mathrm{mM}$ for $24 \mathrm{~h}$ and lysed on ice for $30 \mathrm{~min}$ in $70 \mu \mathrm{l} /$ $10,000,000$ cells of immunoprecipitation lysis buffer $(20 \mathrm{mM}$ HEPES pH 7.9, $0.35 \mathrm{M} \mathrm{NaCl}, 1.0 \mathrm{mM} \mathrm{MgCl}_{2}, 0.5 \mathrm{mM}$ EDTA, 0.1 mM EGTA, 20\% glycerol, 1\% NP-40) containing $1.6 \mathrm{mg} / \mathrm{ml}$ aprotinin, $5.0 \mathrm{mM}$ dithiothreitol (DTT), and $3.0 \mathrm{mM}$ PMSF. Lysates were collected and centrifuged at 12,000 x g for $15 \mathrm{~min}$ at $4^{\circ} \mathrm{C}$. Supernatant protein content was estimated by the Bradford assay (57). Aliquots of cellular lysate (100 $\mu \mathrm{g}$ of proteins) were incubated overnight at $4{ }^{\circ} \mathrm{C}$ with a COX-2specific primary antibody in $50 \mu \mathrm{l}$ of RIPA's buffer $(20 \mathrm{mM}$ Tris-HCl, $150 \mathrm{mM} \mathrm{NaCl}, 10 \mu \mathrm{l} / \mathrm{ml} \mathrm{NP}-40)$ containing $1.6 \mathrm{mg} /$ $\mathrm{ml}$ aprotinin, 5.0 mM DTT, $3.0 \mathrm{mM}$ PMSF and $5.0 \mathrm{mM}$ EDTA. Protein A-Sepharose slurry (15 $\mu$ l) (Sigma-Aldrich) was added to the antibody-treated lysates and incubated for $2 \mathrm{~h}$ at $4^{\circ} \mathrm{C}$. Protein A-Sepharose beads were collected and washed 2 times with RIPA's buffer.

Western blotting. Samples and immunoprecipitates that contained $100 \mu \mathrm{g}$ of proteins were mixed with Laemmli sample buffer and boiled for $5 \mathrm{~min}$ before being loaded into $10 \%$ (COX-1 and COX-2) or 12\% (CYP1A1/1A2) bis-acrylamide gels and separated by SDS polyacrylamide gel electrophoresis. Separated proteins were electrophoretically transferred from gels to nitrocellulose membranes. Blots were blocked for $1 \mathrm{~h}$ in a PBS-0.1\% Tween-20 and 5\% low-fat milk. Membranes were probed overnight at $4{ }^{\circ} \mathrm{C}$ with specific primary antibodies: polyclonal rabbit antibody specific for COX-1 (H-62, Santa Cruz Biotechnology, final dilution 1:500), polyclonal rabbit antibody specific for COX-2 (Cayman Chemical, final dilution 1:200) and polyclonal goat antibody specific for CYP1A1/1A2 (Oxford Biomedical Research, final dilution 1:100). Immunodetection was performed using a chemiluminescence (ECL) kit (Amersham Pharmacia Biotech), according to the manufacturer's instructions. Immunopositive bands were captured by the Kodak Image Station 440CF system and their optical density was analysed using Kodak 1D image analysis software.

Proliferation assays. Cell proliferation was assessed by reduction of 3-(4,5-dimethyl-2-thiazolyl)-2,5-diphenyltetrazolium (MTT, Sigma-Aldrich) to formazan and [methyl${ }^{3} \mathrm{H}$ ]-thymidine incorporation. For the MTT assay (58), cells were seeded at $1.5 \times 10^{4}$ cells/well in 96-well plates. After $48 \mathrm{~h}$ of culture, cells were washed twice with PBS and incubated for $24 \mathrm{~h}$ in $1 \%$ FBS-containing medium in the presence of $\mathrm{SA}$ at concentrations of $0,2.0,2.5,3.0$ and $5.0 \mathrm{mM}$. Absorbance was evaluated using a microplate reader (model 450 , Bio-Rad, USA). Results were expressed as percentage of the corresponding control.

For the $\left[{ }^{3} \mathrm{H}\right]$-thymidine $(25 \mathrm{Ci} / \mathrm{mmol}$, Amersham Pharmacia Biotech) incorporation assay, cells were seeded at $1 \times 10^{4}$ cells/ well in 96-well plates. After $48 \mathrm{~h}$, they were washed twice and incubated for $24 \mathrm{~h}$ in $1 \%$ FBS-containing medium in the presence of SA at the concentrations reported above. Cells were then labelled overnight with $5.0 \mu \mathrm{Ci} / 100 \mu 1$ of [methyl$\left.{ }^{3} \mathrm{H}\right]$-thymidine/well and DNA synthesis was measured as described by Novelli et al (59). Results were expressed as average of cpm taken up by each group of treatment.

Measurement of cell viability. Cell viability was assessed using the following methods: propidium iodide (PI, Sigma-Aldrich) staining assay, lactate dehydrogenase (LDH, Sigma-Aldrich) release, Hoechst-33342 (Sigma-Aldrich) staining assay and DNA analysis.

The PI staining assay is based on necrosis-related cell membrane permeation to IP. Cells were seeded at 30,000 cells/ well on 24-well plates. After $48 \mathrm{~h}$ of culture, cells were washed with PBS and incubated for $24 \mathrm{~h}$ in $1.0 \%$ FBS-containing medium in the presence of SA at concentrations of $0,2.0$, 2.5, 3.0 and $5.0 \mathrm{mM}$. Next, the samples were incubated for $15 \mathrm{~min}$ at room temperature in the dark with $1 \mu \mathrm{g} / 100,000$ cells PI. After incubation, adherent cells were detached using trypsin ( $0.5 \%$ trypsin/0.1\% EDTA in PBS). Detached cells were harvested by centrifugation at $80 \mathrm{x}$ g for $10 \mathrm{~min}$ and resuspended to $0.2 \times 10^{6}$ cells $/ \mathrm{ml}$ in serum-free medium. Cells were applied to glass slides $\left(5 \times 10^{4}\right.$ cells/slide $)$ by cytocentrifugation at $20 \mathrm{x} \mathrm{g}$ for $5 \mathrm{~min}$ (Cytospin cytocentrifuge, Shandon, Inc., Pittsburg, PA). After fixing with ethanol/diethyl ether 1:1 for $10 \mathrm{~min}$ at room temperature, all slides were sealed with glycerol and analyzed using a fluorescent microscope Leica PMIRE-2 with a UV filter and a x40 oil-immersion lens (Leica Microsystem Wetzlar GmbH, Wetzlar, Germany).

The leakage of LDH into the culture medium after exposure of cells to the different concentrations of SA for $24 \mathrm{~h}$ was measured using a colorimetric method (60). Briefly, $0.1 \mathrm{ml}$ samples were mixed with $0.1 \mathrm{ml}$ of $\mathrm{LDH}$ substrate mixture

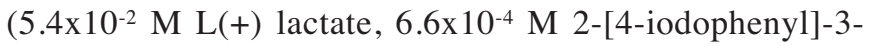
[4-nitrophenyl]-5 phenyl tetrazolium chloride, $2.8 \times 10^{-4} \mathrm{M}$ phenazine methosulphate, $1.3 \times 10^{-3} \mathrm{M} \beta$-nicotinamide adenine dinucleotide in $0.2 \mathrm{M}$ Tris-buffer at $\mathrm{pH} 8.2$ in a 96-flat bottom well microplate (Corning-Celbio-Pero, Italy). The enzymatic reaction was kinetically assessed by microplate $\mathrm{V}_{\max }$ Kinetic Microplate Reader supported by SOFT max (Molecular Devices, Palo Alto, CA, USA) by reading at $490 \mathrm{~nm}$, at room temperature, with a run-time of $10 \mathrm{~min}$ and reading intervals of $5 \mathrm{sec}$. The total release was determined by sonicating untreated cells. The spontaneous release was determined in supernatants from untreated cells. Results were expressed as the percentage of total release.

The Hoechst-33342 staining assay was utilized in order to evaluate changes in cell nuclear morphology after exposure to SA. Cells were cultured, treated and applied to glass slides as described for IP staining. After fixing with ethanol/diethyl ether 1:1 for $10 \mathrm{~min}$ at room temperature, the cells were washed with PBS and incubated for $30 \mathrm{~min}$ at room temperature in the dark in $0.8 \mu \mathrm{M}$ Hoechst-33342/PBS solution. All slides were washed three times with $0.1 \mathrm{M}$ PBS and sealed with glycerol. Nuclear morphology was examined using a fluorescent microscope Leica PMIRE-2 as described for the IP test. Nuclei are considered to have the normal phenotype when glowing bright and homogeneously. Apoptotic nuclei can be identified by condensed chromatin gathering at the periphery of the nuclear membrane or a total fragmented morphology of nuclear bodies.

To evaluate SA cell toxicity, the DNA fragmentation assay was also performed. In brief, cells, cultured and treated as previously described were incubated in $30 \mu 1 / 1 \times 10^{6}$ cell 
Table I. Effect of salicylate on $\left[{ }^{3} \mathrm{H}\right] \mathrm{DMBA}-\mathrm{DNA}$ adduct formation in MCF-7 cells.

\begin{tabular}{lcc}
\hline Group & $\begin{array}{c}\text { fmoles } \\
{ }^{3} \mathrm{H}-\mathrm{DMBA} / \mathrm{mgDNA}{ }^{\mathrm{a}} \\
(\text { mean } \pm \mathrm{SD})\end{array}$ & Statistics \\
\hline Control & $1974 \pm 381$ & - \\
SA $2.0 \mathrm{mM}$ & $1671 \pm 353$ & $\mathrm{~ns}$ \\
SA $2.5 \mathrm{mM}$ & $1330 \pm 320$ & $\mathrm{~b}$ \\
SA $3.0 \mathrm{mM}$ & $709 \pm 340$ & $\mathrm{~b}$ \\
SA $5.0 \mathrm{mM}$ & $639 \pm 389$ & $\mathrm{~b}$
\end{tabular}

${ }^{a}$ Three independent experiments each with $n=3$; ns: not significant. ${ }^{\mathrm{b}} \mathrm{p}<0.05$ vs control.

Table II. Effect of salicylate on $\left[{ }^{3} \mathrm{H}\right] \mathrm{DMBA}-\mathrm{DNA}$ adduct formation in RMTCs.

\begin{tabular}{lcc}
\hline Group & $\begin{array}{c}\text { fmoles } \\
{ }^{3} \mathrm{H}-\mathrm{DMBA} / \mathrm{mgDNA}^{\mathrm{a}} \\
(\text { mean } \pm \text { SD) }\end{array}$ & Statistics \\
\hline Control & $2040 \pm 365$ & - \\
SA $2.0 \mathrm{mM}$ & $1814 \pm 212$ & $\mathrm{~ns}$ \\
SA $2.5 \mathrm{mM}$ & $1391 \pm 150$ & $\mathrm{~b}$ \\
SA $3.0 \mathrm{mM}$ & $551 \pm 130$ & $\mathrm{~b}$ \\
SA $5.0 \mathrm{mM}$ & $533 \pm 147$ & $\mathrm{~b}$ \\
\hline
\end{tabular}

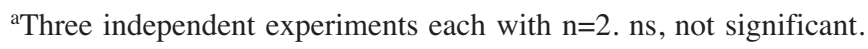
${ }^{\mathrm{b}} \mathrm{p}<0.05$ vs control.

lysis buffer containing $10 \mathrm{mM}$ EDTA, $0.5 \%$ SDS and $0.5 \mathrm{mg} /$ $\mathrm{ml}$ proteinase $\mathrm{K}$ in $50 \mathrm{mM}$ Tris- $\mathrm{HCl}(\mathrm{pH} 8.0)$ for $1 \mathrm{~h}$ at $50^{\circ} \mathrm{C}$. The reaction was stopped in ice and each sample was incubated with $10 \mu \mathrm{g} / \mathrm{ml}$ RNAase for $1 \mathrm{~h}$ at $50^{\circ} \mathrm{C}$. The samples were further incubated for $10 \mathrm{~min}$ at $70^{\circ} \mathrm{C}$ to inactivate both proteinase $\mathrm{K}$ and RNAase. After addition of $0.3 \mathrm{M}$ ammonium acetate, DNA was extracted using cold ethanol, pelleted and resuspended in sterile water. The amount and the pureness of DNA were determined by spectrophotometry. The degree of fragmentation was analyzed using $2 \%$ agarose gel electrophoresis and ethidium bromide staining (61).

Statistical analyses. Data were expressed as means $\pm \mathrm{SD}$ and subjected to one-way ANOVA followed by the Newman-Keuls test to determine the statistical significance of the differences between the experimental groups. A $p<0.05$ was considered significant.

\section{Results}

Effects of SA on DMBA-DNA adduct formation. The effect of SA on DMBA-DNA adduct formation in BCCs was examined in control cultures. Exposure to $0.1 \mu \mathrm{g} / \mathrm{ml}$ [ $\left.{ }^{3} \mathrm{H}\right] \mathrm{DMBA}$ for $24 \mathrm{~h}$ resulted in the formation of $1974 \pm 381$
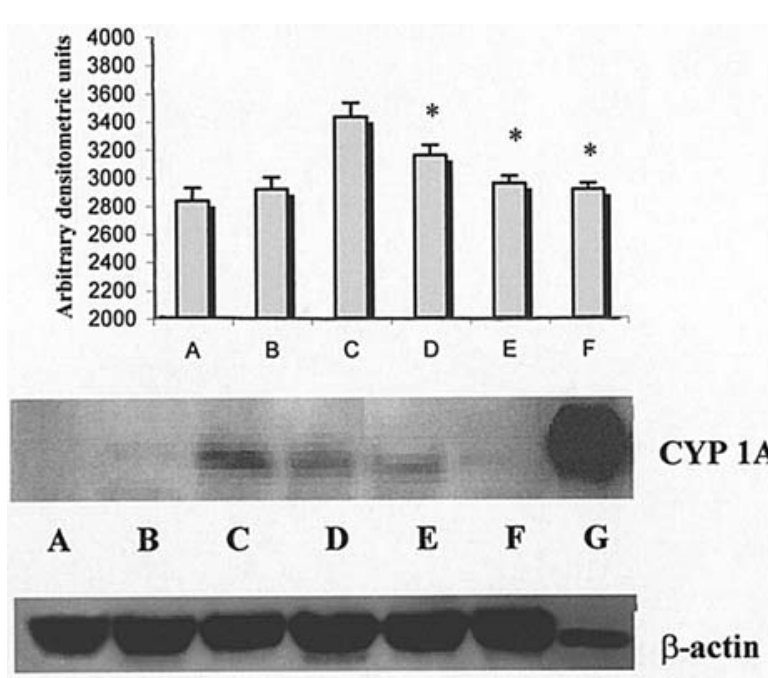

Figure 1. Effects of DMBA or $\beta-N F$ alone or in association with different concentrations of SA on CYP 1A1/1A2 expression in microsomes from MCF-7 cells: A, vehicle; B, DMBA, $10 \mu \mathrm{M}$; C, B-NF $10 \mu \mathrm{M}$; D, B-NF $10 \mu \mathrm{M}$ + SA $2.5 \mathrm{mM}$; E, B-NF $10 \mu \mathrm{M}$ + SA $3.0 \mathrm{mM}$; F, B-NF $10 \mu \mathrm{M}+$ SA $5.0 \mathrm{mM}$; $\mathrm{G}$, positive control (rat liver microsomes induced with $B-\mathrm{NF}$ ). The immunoblots shown in the figure are from one representative experiment out of three. CYP1A1/1A2 levels are expressed as arbitrary units obtained from densitometric scanning analysis of the immunoreactive bands. The same membrane was reprobed with an anti- $\beta$-actin antibody to verify equalization of protein loading in the different lanes. $\mathrm{p}<0.05$ vs $\mathrm{C}(ß-\mathrm{NF})$.

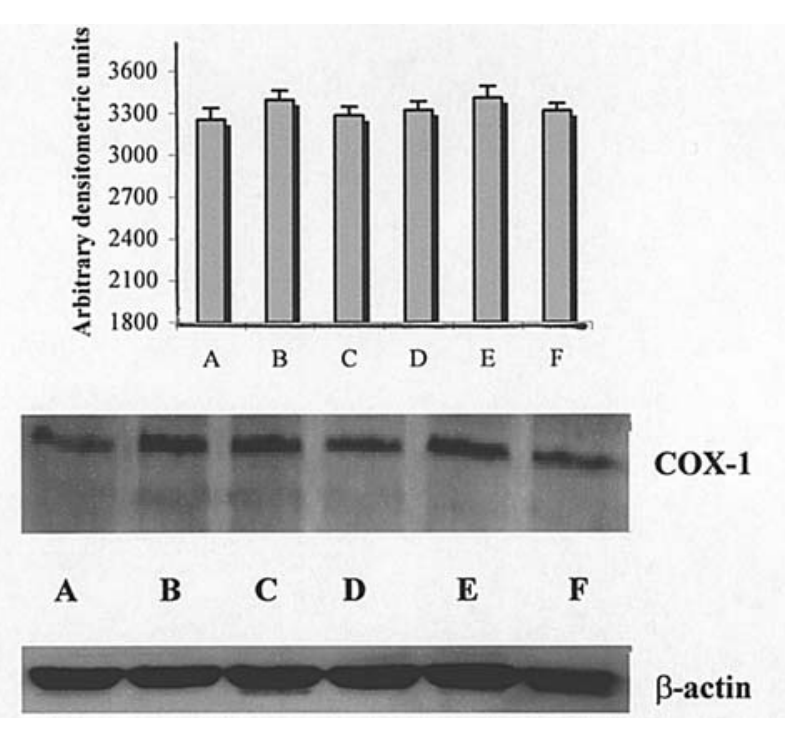

Figure 2. Effects of DMBA alone or in association with different concentrations of SA on COX-1 expression in MCF-7 cells lysate samples: A, vehicle; B, DMBA $1 \mu \mathrm{M}$; C, DMBA $1 \mu \mathrm{M}+\mathrm{SA} 2.0 \mathrm{mM}$; D, DMBA $1 \mu \mathrm{M}+\mathrm{SA} 2.5 \mathrm{mM}$; $\mathrm{E}$, DMBA $1 \mu \mathrm{M}+\mathrm{SA} 3.0 \mathrm{mM}$; F, DMBA $1 \mu \mathrm{M}+\mathrm{SA} 5.0 \mathrm{mM}$. The immunoblots shown in the figure are from one representative experiment out of three. COX-1 levels are expressed as arbitrary units obtained from densitometric scanning analysis of the immunoreactive bands. The same membrane was reprobed with an anti- $\beta$-actin antibody to verify equalization of protein loading in the different lanes.

and 2040 \pm 365 fmoles adducts per mg DNA in MCF-7 cells and in RMTCs, respectively. Exposure of either cell type to $\left[{ }^{3} \mathrm{H}\right] \mathrm{DMBA}$ in the presence of different concentrations of SA significantly reduced DMBA-induced DNA adduct formation at concentrations of $\geq 2.5 \mathrm{mM}$ (Tables I and II). 

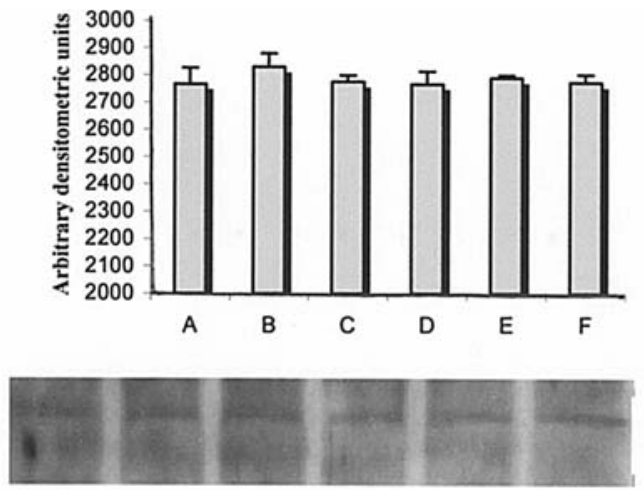

\section{COX-1}

$\begin{array}{llllll}\text { A } & \text { B } & \text { C } & \text { D } & \text { E } & \text { F }\end{array}$

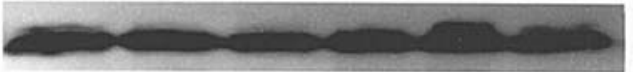

$\beta$-actin

Figure 3. Effects of DMBA alone or in association with different concentrations of SA on COX-1 expression in RMTC lysate samples: A, vehicle; B, DMBA $1 \mu \mathrm{M}$; C, DMBA $1 \mu \mathrm{M}+\mathrm{SA} 2.0 \mathrm{mM}$; D, DMBA $1 \mu \mathrm{M}$ + SA $2.5 \mathrm{mM} ;$ E, DMBA $1 \mu \mathrm{M}+\mathrm{SA} 3.0 \mathrm{mM} ; \mathrm{F}$, DMBA $1 \mu \mathrm{M}+\mathrm{SA} 5.0 \mathrm{mM}$. The immunoblots shown in the figure are from one representative experiment out of three. COX-1 levels are expressed as arbitrary units obtained from densitometric scanning analysis of the immunoreactive bands. The same membrane was reprobed with an anti-ß-actin antibody to verify equalization of protein loading in the different lanes.

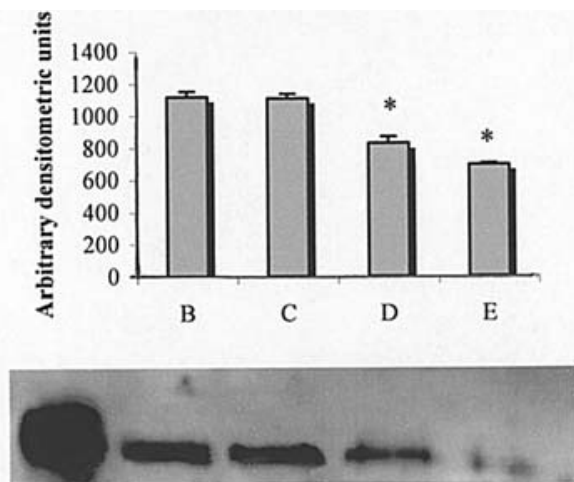

COX-2

A B

C

D

$\mathbf{E}$

Figure 4. Effects of DMBA alone or in association with SA 2.5 or $5.0 \mathrm{mM}$ on COX-2 expression in immunoprecipitates from RMTCs: A, positive control (COX-2 Electrophoresis Standard, Cayman Chemical); B, vehicle; C, DMBA $1 \mu \mathrm{M}$; D, DMBA $1 \mu \mathrm{M}+\mathrm{SA} 2.5 \mathrm{mM}$; E, DMBA $1 \mu \mathrm{M}+\mathrm{SA}$ $5.0 \mathrm{mM}$. The immunoblot shown in the figure is from one representative experiment out of three. COX-2 levels are expressed as arbitrary units obtained from densitometric scanning analysis of the immunoreactive bands. ${ }^{*} \mathrm{p}<0.05$ vs $\mathrm{C}$ (DMBA)

SA-mediated modulation of CYPIA, COX-1 and COX-2. CYP1A: immunoblots carried out in microsomal fractions with the appropriate antibody to assess the constitutive expression and induction of CYP1A in each cell type showed a very low protein expression in untreated MCF-7 cells. Following treatment with $10 \mu \mathrm{M}$ DMBA, there was a slight and not significant increase in CYP1A1/1A2 immunoreactive protein. In contrast, protein expression was more notably enhanced $(+17 \%)$ in microsomes from $10 \mu \mathrm{M} \beta-\mathrm{NF}$ treated cells; this phenomenon was significantly inhibited by SA in a concentration-dependent manner (Fig. 1). CYP1A1/1A2 was

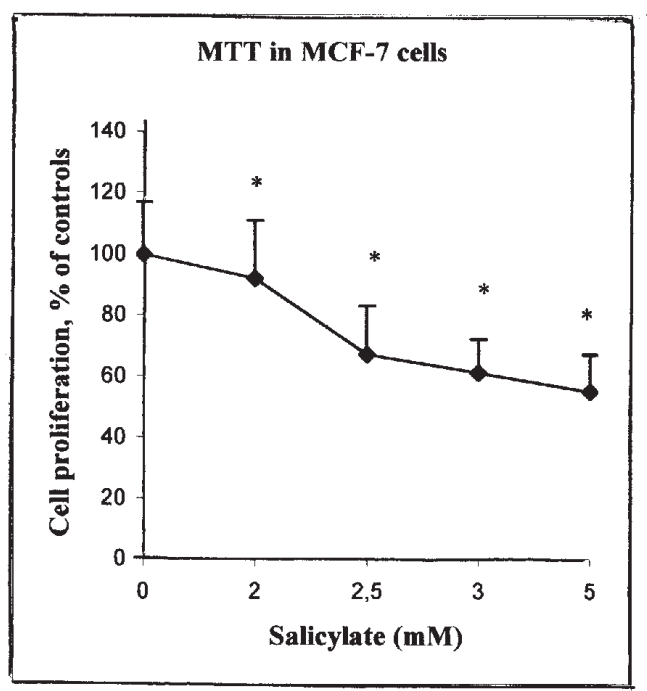

Figure 5. Salicylate effect on MCF-7 cell proliferation determined by MTT assay. Results are expressed as percentage of the control value (mean $\pm \mathrm{SD}$ from 3 independent experiments, each with $\mathrm{n}=8$ ). ${ }^{*} \mathrm{p}<0.05$ vs control (SA $0 \mathrm{mM})$.

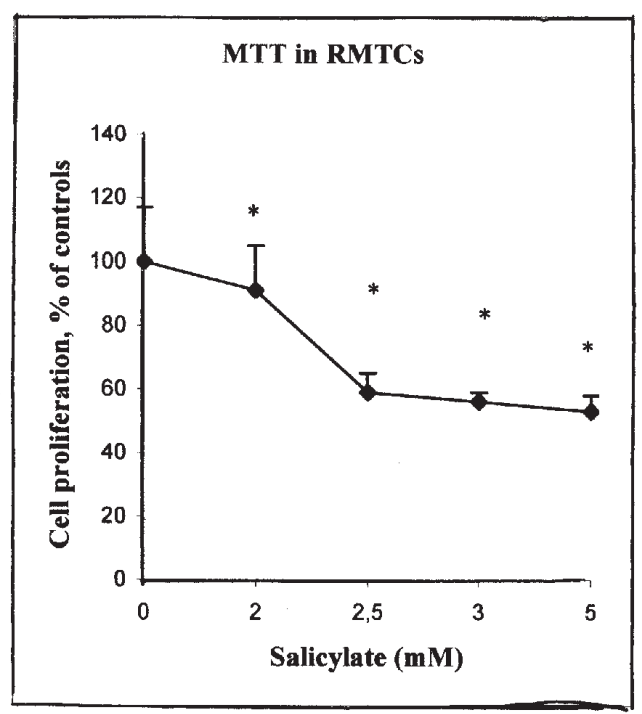

Figure 6. Salicylate effect on RMTC proliferation determined by MTT assay. Results are expressed as percentage of the control value (mean \pm SD from 3 independent experiments, each with $\mathrm{n}=8)$. ${ }^{*} \mathrm{p}<0.05$ vs control (SA $\left.0 \mathrm{mM}\right)$.

seemingly neither constitutively expressed nor induced in RMTCs under the same conditions (data not shown).

COX-1 and COX-2: immunoblotting results (Figs. 2 and 3) indicated that blots for COX-1 protein from MCF-7 cells and RMTCs were similar. COX-1 expression was little affected by DMBA alone and the concurrent exposure to SA did not result in appreciable changes in the enzyme expression, irrespective of the cell source. COX-2 was undetectable in MCF-7 cells (data not shown), but clearly detectable in RMTCs. COX-2 expression was seemingly not modified by DMBA alone, while cells exposed to both DMBA and SA displayed a significant decrease in protein signal (Fig. 4).

Effects of SA on breast cancer proliferation. MCF-7 cells and RMTCs were incubated for $24 \mathrm{~h}$ with SA at concentrations 


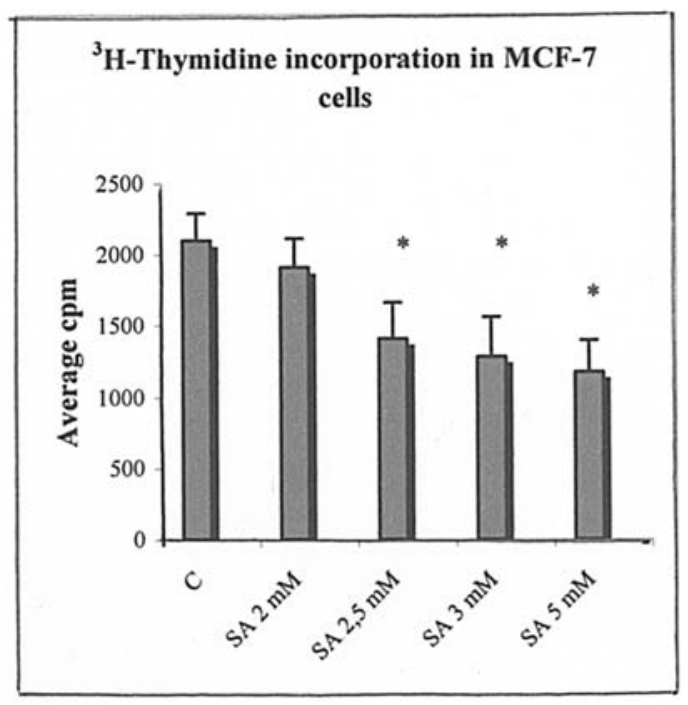

Figure 7. $\left[{ }^{3} \mathrm{H}\right]$-thymidine incorporation in MCF-7 cells treated with increasing doses of salicylate for $24 \mathrm{~h}$. Results are expressed as average of $\mathrm{cpm}$ taken up by each group of treatment (mean \pm SD from 3 independent experiments, each with $n=2)$. ${ }^{*} p<0.05$ vs control (C).

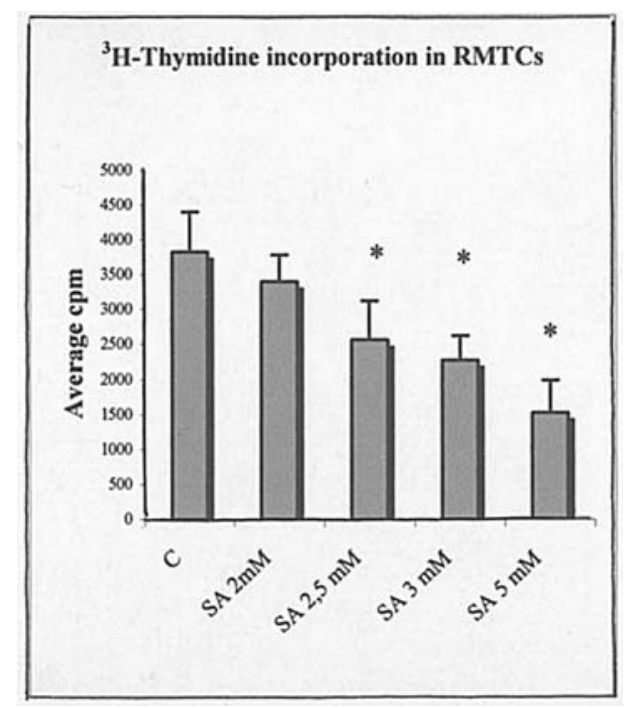

Figure 8. $\left[{ }^{3} \mathrm{H}\right]$-thymidine incorporation in RMTCs treated with increasing doses of salicylate for $24 \mathrm{~h}$. Results are expressed as average of cpm taken up by each group of treatment (mean \pm SD from 3 independent experiments, each with $\mathrm{n}=2$ ). ${ }^{*} \mathrm{p}<0.05$ vs control (C).

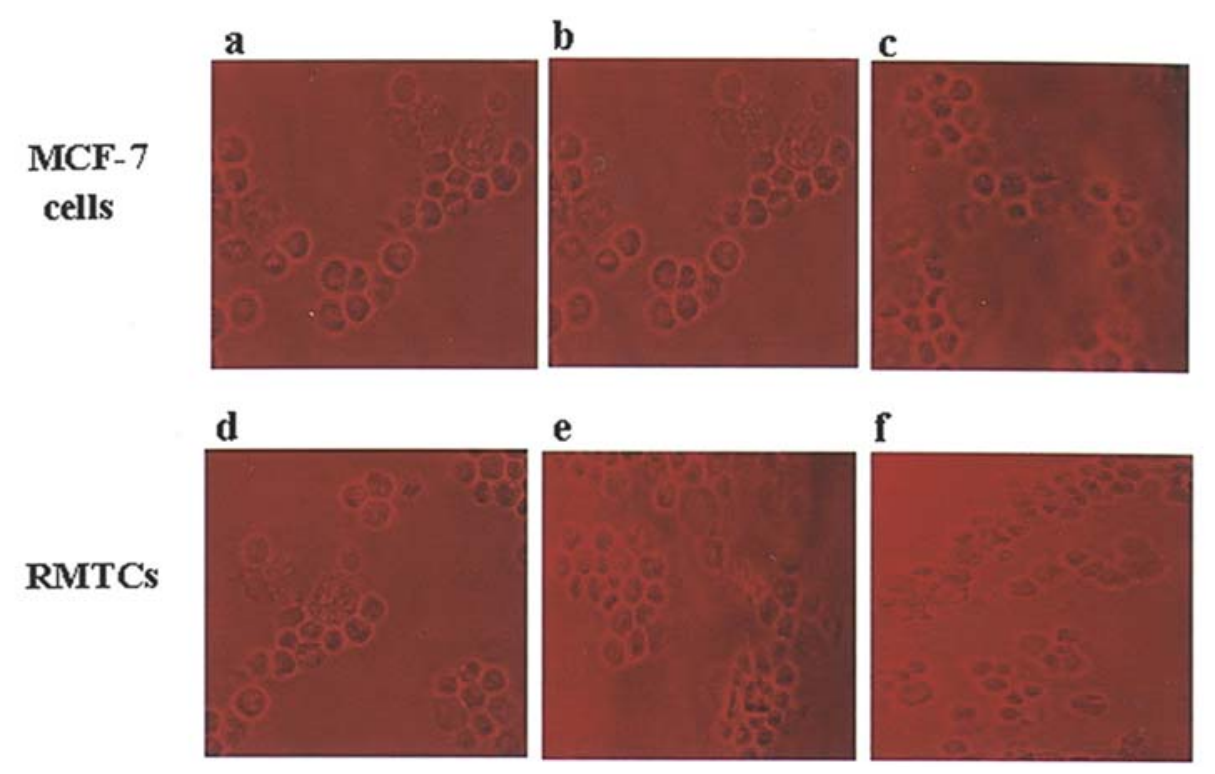

Figure 9. Morphological features of PI-stained BCCs either untreated (a and d) or exposed for $24 \mathrm{~h}$ to SA $2 \mathrm{mM}$ (b and e) or $5 \mathrm{mM}$ (c and f). The PI assay is based on necrosis-related cell membrane permeation to PI. Fluorescent microphotographs of PI-stained BCCs demonstrate that SA treatment did not modify cytoplasmic membrane integrity.

ranging from 2.0 to $5.0 \mathrm{mM}$. As revealed by the MTT assay, SA significantly decreased the number of both types of BCC at concentrations of $\geq 2.0 \mathrm{mM}$ (Figs. 5 and 6 ). $\left[{ }^{3} \mathrm{H}\right]$-thymidine incorporation studies showed that, after 24-h incubation, the inhibition of DNA replication by SA was significant at concentrations of $\geq 2.5 \mathrm{mM}$ (Figs. 7 and 8 ).

Effects of SA on breast cancer cell viability. The evaluation of SA cell toxicity was performed using different assays to discriminate between necrosis and apoptosis. As assessed by the PI assay (Fig. 9), neither of the BCCs exhibited any morphological change after the exposure for $24 \mathrm{~h}$ to $\mathrm{SA}$ at the lowest $(2.0 \mathrm{mM})$ or highest $(5.0 \mathrm{mM})$ tested concentrations.
Likewise, cell damage evaluated in terms of LDH release was not induced by SA treatment (Fig. 10). We used Hoechst 33342 staining and DNA ladder assay to study the effects of SA on apoptosis. No apoptotic bodies containing nuclear fragments were found in BCCs exposed to SA 2.0 or $5.0 \mathrm{mM}$ for $24 \mathrm{~h}$ (Fig. 11). Gel electrophoresis of DNA from BCCs treated with increasing concentrations of SA for $24 \mathrm{~h}$ revealed a 'ladder' pattern that indicated no DNA degradation (Figs. 12 and 13).

\section{Discussion}

The present study shows that treatment of mammary cancer cells for $24 \mathrm{~h}$ with different concentrations of SA inhibits 


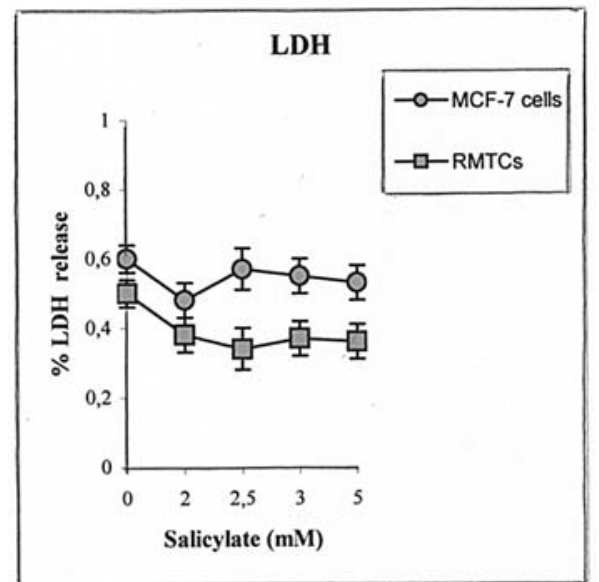

Figure 10. Effect of different concentrations of SA on lactate dehydrogenase (LDH) release of MCF-7 cells and RMTCs. Results are expressed as percentage of total release.

DMBA-DNA adduct formation, a phenomenon which is generally accepted as a critical step in the mechanism by which polycyclic aromatic hydrocarbons (PAHs) cause mutations leading to the induction of cancer in the target organs (62). The exposure of cells to $2.5 \mathrm{mM}$ SA results in a significant inhibition of DMBA-DNA adduct formation that reaches a maximum value at $3.0 \mathrm{mM}$, a concentration compatible with drug plasma levels measurable during treatment of chronic inflammatory diseases $(63,64)$. This effect may contribute to the aspirin breast cancer chemopreventive action observed in clinical trials and epidemiological and experimental studies; it also indicates that this drug can act in the first stage of carcinogenesis. As mentioned above, DMBA, in common

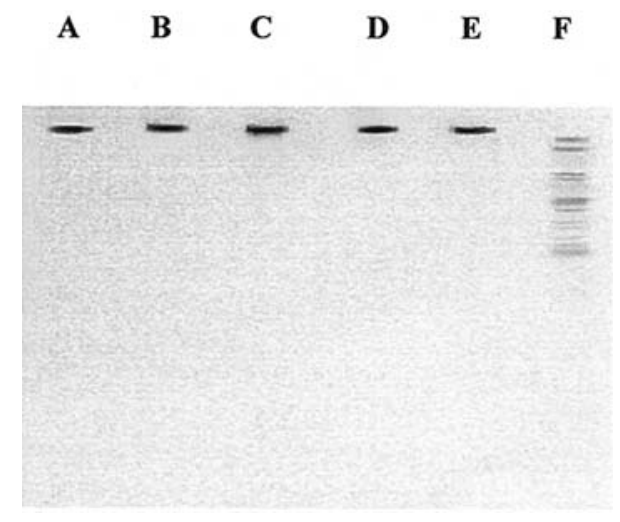

Figure 12. Analysis of DNA fragmentation by agarose gel electrophoresis after treatment of MCF-7 cells with different concentrations of SA: A, no treatment; B, SA $2.0 \mathrm{mM}$; C, SA $2.5 \mathrm{mM}$; D, SA $3.0 \mathrm{mM}$; E, SA $5.0 \mathrm{mM}$; F $1 \mathrm{~kb}$ DNA marker. The result presented is typical of 3 separate experiments.

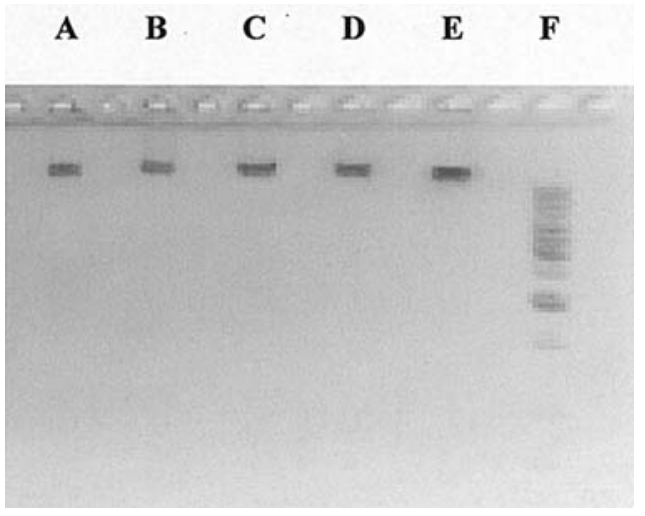

Figure 13. Analysis of DNA fragmentation by agarose gel electrophoresis after treatment of RMTC cells with different concentrations of SA: A, no treatment; B, SA $2.0 \mathrm{mM}$; C, SA $2.5 \mathrm{mM}$; D, SA $3.0 \mathrm{mM}$; E, SA $5.0 \mathrm{mM}$; F $1 \mathrm{~kb}$ DNA marker. The result presented is typical of 3 separate experiments.

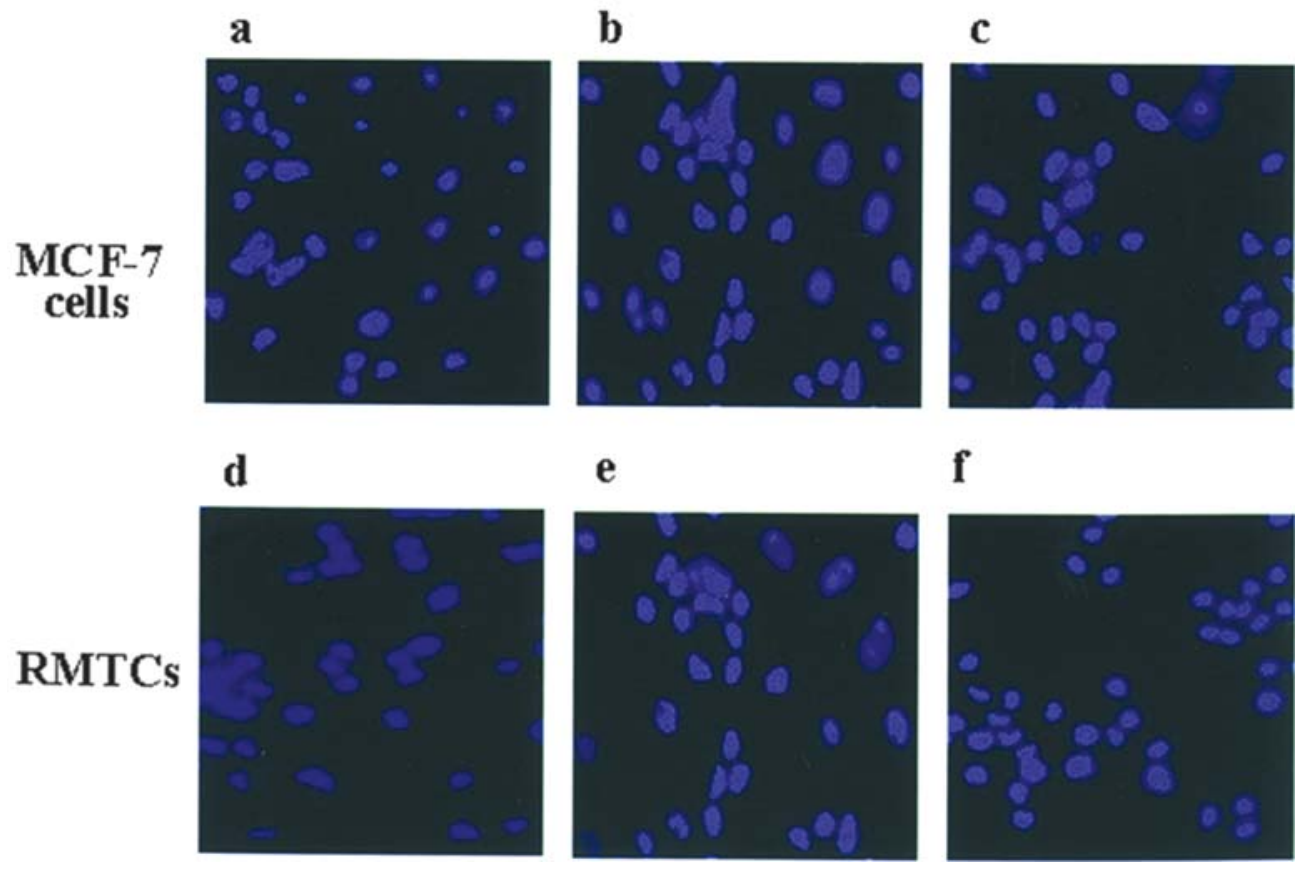

Figure 11. Morphological features of Hoechst 33342-stained BCCs either untreated (a and d) or exposed for 24 h to SA 2 mM (b and e) or 5 mM (c and f). Hoechst 33342-staining was used to visualize chromatin condensation or fragmentation, a typical phenomenon of cells undergoing apoptosis. Fluorescent microphotographs of Hoechst 33342-stained BCCs indicate no apoptotic nuclei (condensed or fragmented) after exposure to SA. 
with other PAHs, requires metabolic activation by CYPdependent monooxygenases, mainly CYP1A isoforms, or other oxidases before it can induce malignant transformation. As reported in the literature, prior exposure of MCF-7 cells to CYP inducers, such as PAHs or $\mathrm{B}-\mathrm{NF}$, enhances CYP1A1 expression (47-49). In our experiments, CYP1A was markedly induced by $B-N F$ and less by DMBA. Since both chemicals share a common induction mechanism, we evaluated the effects of SA on CYP1A1/1A2 expression in cells exposed to B-NF. As detected by Western blotting, microsomes from B-NFtreated MCF-7 cells showed a significant decrease in this protein after SA exposure. In contrast, we did not observe constitutive or inducible CYP1A1/1A2 protein in RMTCs. Both the expression and induction of this enzyme have been well documented in rat mammary glands (65) but, to the best of our knowledge, there is no study on CYP1A1 expression in DMBA-induced mammary tumours. Indeed, there are extensive studies on CYP expression in chemically-induced rat/mouse liver tumours revealing a decrease of the expression of this enzyme in hepatic tumours compared with adjacent non-neoplastic tissue (66-68). As reported by Williams and Phillips (33), COX may play an important role in carcinogen bioactivation in extrahepatic tissue, expecially where CYPmediated enzyme activity is low. Western blot analysis revealed the presence of COX-1 in both cell types. In line with the results of Din et al (69), COX-2 was not detectable in MCF-7 cells, but was present in RMTCs in agreement with Ghezzo et al (50), who reported COX-2 expression in DMBA-induced rat mammary tumours. Prior exposure of cells to DMBA did not affect COX expression. There have been no studies reporting a direct induction of COX expression after exposure of cells or animal tissue to DMBA. Jang et al (12) investigated the expression of COX-1 and COX-2 in normal rat mammary glandular epithelium and in the various stages of DMBA-induced rat mammary carcinogenesis. They observed negligible COX-1 expression and no COX-2 expression in normal mammary glands; DMBA treatment, in itself, did not modify COX expression. On the contrary, DMBA-induced mammary gland neoplastic transformation enhanced COX-1 expression and induced COX-2 expression in a high percentage of tumours. Data from the present study indicate that SA addition did not affect COX-1 expression in BCCs but inhibited COX-2 expression in RMTCs. Until recently, there were no studies examining the effect of aspirin on COX-1 gene expression in human breast cancer or rodent mammary tumours, although Robertson et al (70) reported that ibuprofen was able to inhibit COX-1 and COX-2 gene expression in DMBA-induced rat mammary tumours. Even so, we can assume that SA inhibits COX-1 activity in BCCs by a well-known mechanism, i.e. rapid reversible binding followed by covalent modification (acetylation) of Ser 530 of COX-1 (71). Although the exact mechanism by which SA inhibits DMBA-DNA adduct formation in BCCs remains to be established, according to our results this effect may be due to SA's ability to decrease the expression of the enzymes involved in carcinogen bioactivation.

Since several reports suggest inhibiton of tumour cell growth and induction of apoptosis as two possible explanations for the anti-tumour effects of NSAIDs (72), we have also investigated the effects of SA on BCC proliferation and viability in vitro. In line with the results of previous investigations $(21,28,73)$, SA proved effective in the inhibition of $\mathrm{BCC}$ growth but failed to cause cell death by necrosis or apoptosis. The latter finding is in contrast with previous reports on NSAID-induced apoptosis in breast cancer cells but agrees with the results of Din et al (69), who showed that aspirin had no effect on viability and apoptosis in breast cancer cell lines. These differences may be explained by considering that induction of apoptosis was observed in studies using NSAIDs other than aspirin $(20,23,74,75)$, while SA-induced apoptosis was observed only after long exposures (48-96 h) to high concentrations of drug beyond the therapeutic range (73).

In conclusion, the present study demonstrates that SA significantly inhibits cell proliferation and DMBA-DNA adduct formation in the two tested types of BCC at concentrations which do not affect cell viability. The latter effect is possibly mediated via modulation of the expression of the enzymes involved in carcinogen bioactivation (CYP1A1/1A2 and COX), even if it is not possible to exclude other mechanisms, such as the induction of phase II detoxifying enzymes. Inhibition of adduct formation by SA represents a further mechanism responsible for aspirin chemopreventive efficacy that can be added to the several antitumour actions previously documented for NSAIDs. In our opinion, the antitumour effect exerted by SA and related agents is probably due to different actions of the drugs, strictly correlated in many cases, that collectively contribute to the final effect.

\section{Acknowledgements}

This work was supported by the Italian Ministry of University and Research (M.I.U.R.) (ex 60\%).

\section{References}

1. Sporn MB and Suh N: Chemoprevention of cancer. Carcinogenesis 21: 525-530, 2000.

2. Swede H, Mirand AL, Menezes RJ and Moysich KB: Association of regular aspirin use and breast cancer risk. Oncology 68: 40-47, 2005.

3. Schreinemachers DM and Everson RB: Aspirin use and lung, colon, and breast cancer incidence in a prospective study. Epidemiology 5: 138-146, 1994.

4. Harris RE, Namboodiri KK and Farrar WB: Non-steroidal antiinflammatory drugs and breast cancer. Epidemiology 7: 203-205, 1996.

5. Harris RE, Kasbari S and Farrar WB: Prospective study of nonsteroidal anti-inflammatory drugs and breast cancer. Oncol Rep 6: 71-73, 1999.

6. Sharpe CR, Collet JP, McNutt M, Belzile E, Boivin JF and Hanley JA: Nested case-control study of the effects of nonsteroidal anti-inflammatory drugs on breast cancer risk and stage. Br J Cancer 83: 112-120, 2000.

7. Cotterchio M, Kreiger N, Sloan M and Steingart A: Nonsteroidal anti-inflammatory drug use and breast cancer risk. Cancer Epidemiol Biomarkers Prev 10: 1213-1217, 2001.

8. Johnson TW, Anderson KE, Lazovich D and Folsom AR: Association of aspirin and non-steroidal anti-inflammatory drug use with breast cancer. Cancer Epidemiol Biomarkers Prev 11: 1586-1591, 2002.

9. Harris RE, Chlebowski RT, Jackson RD, Frid DJ, Ascenseo J1, Anderson G, Loar A, Rodabough RJ, White E, McTiernan A, Women's Health Initiative: Breast cancer and non-steroidal antiinflammatory drugs: prospective results from the Women's Health Initiative. Cancer Res 63: 6096-6101, 2003.

10. Khuder SA and Mutgi AB: Breast cancer and NSAID use: a meta-analysis. Br J Cancer 84: 1188-1192, 2001. 
11. Terry MB, Gammon MD, Zhang FF, Tawfik H, Teitelbaum SL, Britton JA, Subbaramaiah K, Dannenberg AJ and Neugut AI: Association of frequency and duration of aspirin use and hormone receptor status with breast cancer risk. JAMA 291: 2433-2440, 2004.

12. Jang TJ, Jung HG, Jung $\mathrm{KH}$ and $\mathrm{O}$ MK: Chemopreventive effect of celecoxib and expression of cyclooxygenase-1 and cyclooxygenase-2 on chemically-induced rat mammary tumours. Int J Exp Pathol 83: 173-182, 2002.

13. Lu S, Zhang X, Badawi AF, El-Sohemy A and Archer MC: Cyclooxygenase-2 inhibitor celecoxib inhibits promotion of mammary tumorigenesis in rats fed a high fat diet rich in n-6 polyunsaturated fatty acids. Cancer Lett 184: 7-12, 2002.

14. Abou-Issa HM, Alshafie GA, Seibert K, Koki AT, Masferrer JL and Harris RE: Dose-response effects of the COX-2 inhibitor, celecoxib, on the chemoprevention of mammary carcinogenesis. Anticancer Res 21: 3425-3432, 2001.

15. Alshafie GA, Abou-Issa HM, Seibert K and Harris RE: Chemotherapeutic evaluation of Celecoxib, a cyclooxygenase-2 inhibitor, in a rat mammary tumor model. Oncol Rep 7: 1377-1381, 2000.

16. Harris RE, Alshafie GA, Abou-Issa H and Seibert K: Chemoprevention of breast cancer in rats by celecoxib, a cyclooxygenase 2 inhibitor. Cancer Res 60: 2101-2103, 2000.

17. McCormick DL, Madigan MJ and Moon RC: Modulation of rat mammary carcinogenesis by indomethacin. Cancer Res 45: 1803-1808, 1985.

18. Kubatka P, Ahlers I, Ahlersova E, Adamekova E, Luk P, Bojkova B and Markova M: Chemoprevention of mammary carcinogenesis in female rats by rofecoxib. Cancer Lett 202: $131-136,2003$

19. Kundu N and Fulton AM: Selective cyclooxygenase (COX)-1 or COX-2 inhibitors control metastatic disease in a murine model of breast cancer. Cancer Res 62: 2343-2346, 2002.

20. Han EK, Arber N, Yamamoto H, Lim JT, Delohery T, Pamukcu R, Piazza GA, XingWQ and Weinstein IB: Effects of sulindac and its metabolites on growth and apoptosis in human mammary epithelial and breast carcinoma cell lines. Breast Cancer Res Treat 48: 195-203, 1998.

21. Kundu N, Smyth MJ, Samsel L and Fulton AM: Cyclooxygenase inhibitors block cell growth, increase ceramide and inhibit cell cycle. Breast Cancer Res Treat 76: 57-64, 2002.

22. Oh KW, Qian T, Brenner DA and Lemasters JJ: Salicylate enhances necrosis and apoptosis mediated by the mitochondrial permeability transition. Toxicol Sci 73: 44-52, 2003.

23. Basu GD, Pathangey LB, Tinder TL, Lagioia M, Gendler SJ and Mukherjee P: Cyclooxygenase-2 inhibitor induces apoptosis in breast cancer cells in an in vivo model of spontaneous metastatic breast cancer. Mol Cancer Res 2: 632-642, 2004.

24. Prosperi JR, Mallery SR, Kigerl KA, Erfurt AA and Robertson FM: Invasive and angiogenic phenotype of MCF-7 human breast tumor cells expressing human cyclooxygenase- 2 . Prostaglandins Other Lipid Mediat 73: 249-264, 2004.

25. Fife RS, Stott B and Carr RE: Effects of a selective cyclooxygenase- 2 inhibitor on cancer cells in vitro. Cancer Biol Ther 3: 228-232, 2004

26. Connolly EM, Harmey JH, O'Grady T, Foley D, Roche-Nagle G, Kay E and Bouchier-Hayes DJ: Cyclo-oxygenase inhibition reduces tumour growth and metastasis in anorthotopic model of breast cancer. Br J Cancer 87: 231-237, 2002.

27. Rozic JG, Chakraborty C and Lala PK: Cyclooxygenase inhibitors retard murine mammary tumor progression by reducing tumor cell migration, invasiveness and angiogenesis. Int J Cancer 93: 497-506, 2001

28. Levitt RJ, Buckley J, Blouin MJ, Schaub B, Triche TJ and Pollak M: Growth inhibition of breast epithelial cells by celecoxib is associated with upregulation of insulin-like growth factor binding protein-3 expression. Biochem Biophys Res Commun 316: 421-428, 2004.

29. Teh SH, Hill AK, Foley DA, McDermott EW, O'Higgins NJ and Young LS: COX inhibitors modulate bFGF-induced cell survival in MCF-7 breast cancer cells. J Cell Biochem 91: 796-807, 2004.

30. Simeone AM, Li YJ, Broemeling LD, Johnson MM, Tuna M and Tari AM: Cyclooxygenase-2 is essential for HER2/neu to suppress N-(4-hydroxyphenyl)retinamide apoptotic effects in breast cancer cells. Cancer Res 64: 1224-1228, 2004.

31. Timoshenko AV, Xu G, Chakrabarti S, Lala PK and Chakraborty C: Role of prostaglandin E2 receptors in migration of murine and human breast cancer cells. Exp Cell Res 289: 265-274, 2003
32. Miller EC and Miller JA: Mechanisms of chemical carcinogenesis. Cancer 47: 1055-1064, 1981

33. Williams JA and Phillips DH: Mammary expression of xenobiotic metabolizing enzymes and their potential role in breast cancer. Cancer Res 60: 4667-4677, 2000.

34. Hwang D, Scollard D, Byrne J and Levine E: Expression of cyclooxygenase- 1 and cyclooxygenase- 2 in human breast cancer. J Natl Cancer Inst 90: 455-460, 1998.

35. Singletary KW, Nelshoppen JM, Scardefield S and Wallig M Inhibition by butylated hydroxytoluene and its oxidative metabolites of DMBA-induced mammary tumorigenesis and of mammary DMBA-DNA adduct formation in vivo in the female rat. Food Chem Toxicol 30: 455-465, 1992.

36. Singletary KW, MacDonald $\mathrm{C}$ and Wallig $\mathrm{M}$ : Inhibition by rosemary and carnosol of 7,12-dimethylbenz[a]anthracene (DMBA)-induced rat mammary tumorigenesis and in vivo DMBA-DNA adduct formation. Cancer Lett 104: 43-48, 1996.

37. Singletary KW, MacDonald C, Wallig M and Fisher C: Inhibition of 7,12- dimethylbenz[a]anthracene (DMBA)-induced mammary tumorigenesis and DMBA-DNA adduct formation by curcumin. Cancer Lett 103: 137-141, 1996.

38. Singletary KW, MacDonald C and Wallig M: The plasticizer benzyl butyl phthalate (BBP) inhibits 7,12-dimethylbenz[a] anthracene (DMBA)-induced rat mammary DNA adduct formation and tumorigenesis. Carcinogenesis 18: 1669-1673, 1997

39. Liu J, Gilbert K, Parker HM, Haschek WM and Milner JA Inhibition of 7,12-dimethylbenz(a)anthracene-induced mammary tumors and DNA adducts by dietary selenite. Cancer Res 51: 4613-4617, 1991.

40. El-Bayoumi K, Chae YH, Upadhyaya P, Meschter C, Cohen LA and Reddy BS: Inhibition of 7-12-dimethylbenz[a]anthracene (DMBA)-induced tumors and DNA adduct formation in the mammary glands of female Sprague-Dawley rats by the synthetic organoselenium compound, 1,4-phenyl-enebis(methylene) selenocyanate. Cancer Res 52: 2402-2407, 1992.

41. Das SK, Jia TZ, Bandyopadhyay AM and Banerjee MR: Bcarotene-mediated inhibition of a DNA adduct induced by 7-12dimethylbenz(a)anthracene and 7-hydroxymethyl-12-methylbenz $(a)$ anthracene in mouse mammary gland in vitro. Eur $\mathbf{J}$ Cancer 28: 1124-1129, 1992.

42. Ip C, Vadhanavikit S and Ganther H: Cancer chemoprevention by aliphatic selenocyanates: effect of chain length on inhibition of mammary tumors and DMBA adducts. Carcinogenesis 16: 35-38, 1995

43. Amagase H, Schaffer EM and Milner JA: Dietary components modify the ability of garlic to suppress 7,12-dimethylbenz(a) anthracene-induced mammary DNA adducts. J Nutr 126: 817-824, 1996.

44. Schaffer EM, Liu JZ and Milner JA: Garlic powder and allyl sulfur compounds enhance the ability of dietary selenite to inhibit 7,12-dimethylbenz[a] anthracene-induced mammary DNA adducts. Nutr Cancer 27: 162-168, 1997.

45. Ciolino HP and Yeh GC: The flavonoid galangin is an inhibitor of CYP1A1 activity and an agonist/antagonist of the aryl hydrocarbon receptor. Br J Cancer 79: 1340-1346, 1999.

46. Ciolino HP, MacDonald CJ and Yeh GC: Inhibition of carcinogenactivating enzymes by 16alpha-fluoro-5-androsten-17-one. Cancer Res 62: 3685-3690, 2002.

47. Larsen MC, Angus WG, Brake PB, Elpton SE, Sukow KA and Jefcoate CR: Characterization of CYP1B1 and CYP1A1 expression in human mammary epithelial cells: role of the aryl hydrocarbon receptor in polycyclic aromatic hydrocarbon metabolism. Cancer Res 58: 2366-2374, 1998

48. Mahadevan B, Keshava C, Musafia-Jeknic T, Pecaj A, Weston A and Baird WM: Altered gene expression patterns in MCF-7 cells induced by the urban dust particulate complex mixture standard reference material 1649a. Cancer Res 65: 1251-1258, 2005 .

49. Mahadevan B, Parsons H, Musafia T, Sharma AK, Amin S, Pereira C and Baird WM: Effect of artificial mixtures of environmental polycyclic aromatic hydrocarbons present in coal tar, urban dust, and diesel exhaust particulates on MCF-7 cells in culture. Environ Mol Mutagen 44: 99-107, 2004.

50. Ghezzo F, Cesano L, Mognetti B, Pesce E, Pirro E, Corvetti G, Berta GN, Zingaro B and Di Carlo F: Salicylate inhibition of rat mammary carcinogenesis and angiogenesis in female rat compatible with misoprostol administration. Int J Oncol 26: 697-702, 2005. 
51. Yamashita J, Horiuchi S, Shigaki N, Fujino N and Akagi M: Estrogen-dependent plasminogen activator in 7,12-dimethylbenz[a]anthracene-induced rat mammary tumors in vivo and in vitro. Gann 75: 681-689, 1984.

52. Moore CJ, Tricomi WA and Gould MN: Interspecies comparison of polycyclic aromatic hydrocarbon metabolism in human and rat mammary epithelial cells. Cancer Res 46: 4946-4952, 1986.

53. Nebert DW: Genetic differences in the microsomal electron transport: the Ah locus. In: Methods in Enzymology. Fleischer S and Packer L (eds). New York Academic Press, pp227-240, 1978.

54. Miller SA, Dykes DD and Polesky HF: A simple salting out procedure for extracting DNA from human nucleated cells. Nucleic Acids Res 16: 1215, 1988.

55. Lowry OH, Rosebrough NJ, Farr AL and Randal RJ: Protein measurement with Folin phenol reagent. J Biol Chem 193: 265, 1951.

56. Pham H, Banerjee T and Ziboh VA: Suppression of cyclooxygenase- 2 overexpression by 15 s-hydroxyeicosatrienoic acid in androgen-dependent prostatic adenocarcinoma cells. Int J Cancer 111: 192-197, 2004.

57. Bradford MM: A rapid and sensitive method for quantitation of microgram quantities of protein utilizing the principle of protein dye-binding. Anal Biochem 72: 248-254, 1976.

58. Twentyman PR and Luscombe M: A study of some variables in a tetrazolium dye-(MTT) based assay for cell growth and chemosensitivity. Br J Cancer 56: 279-285, 1987.

59. Novelli F, Giovarelli M, Reber-Liske R, Virgallita G, Garotta G and Forni G: Blockade of physiologically secreted IFN- $\gamma$ inhibits human T lymphocyte and natural killer cell activation. J Immunol 147: 1445-1452, 1991.

60. Korzeniewsky $\mathrm{C}$ and Callewaert DM: An enzyme release assay for natural cytotoxicity. J Immunol Methods 64: 313-320, 1983.

61. Maniatis T, Fritsch EF and Sambrook J: Molecular cloning. A laboratory manual. Cold Spring Harbor Laboratory, pp157-161, 1982.

62. Dipple A, Moschel RC and Bigger CAH: Polynuclear aromatic carcinogens. In: Chemical Carcinogens. Searle CE (ed). ACS Monographs American Chemical Society, Washington, DC, pp41-174, 1984.

63. Grilli M, Pizzi M, Memo M and Spano P: Neuroprotection by aspirin and sodium salicylate through blockade of NF-kappaB activation. Science 274: 1383-1385, 1996.
64. Yin M-J, Yamamoto Y and Gaynor RB: The anti-inflammatory agents aspirin and salicylate inhibit the activity of IкB kinase- $B$. Nature 396: 77-80, 1998.

65. Rowlands JC, He L, Hakkak R, Ronis MJ and Badger TM: Soy and whey proteins downregulate DMBA-induced liver and mammary gland CYP1 expression in female rats. J Nutr 131: 3281-3287, 2001.

66. Buchmann A, Kuhlmann W, Schwarz M, Kunz W, Wolf CR, Moll E, Friedberg T and Oesch F: Regulation and expression of four cytochrome P-450 isoenzymes, NADPH-cytochrome P-450 reductase, the glutathione transferases $\mathrm{B}$ and $\mathrm{C}$ and microsomal epoxide hydrolase in preneoplastic and neoplastic lesions in rat liver. Carcinogenesis 6: 513-521, 1985.

67. Roomi MW, Ho RK, Sarma DS and Farber E: A common biochemical pattern in preneoplastic hepatocyte nodules generated in four different models in the rat. Cancer Res 45: 564-571, 1985

68. Stout DL and Becker FF: Xenobiotic metabolizing enzymes in genetically and chemically initiated mouse liver tumors. Cancer Res 46: 2693-2696, 1986.

69. Din FV, Dunlop MG and Stark LA: Evidence for colorectal cancer cell specificity of aspirin effects on NF kappaB signalling and apoptosis. Br J Cancer 91: 381-388, 2004.

70. Robertson FM, Parrett ML, Joarder FS, Ross M, Abou-Issa HM, Alshafie $\mathrm{G}$ and Harris RE: Ibuprofen-induced inhibition of cyclooxygenase isoform gene expression and regression of rat mammary carcinomas. Cancer Lett 122: 165-175, 1998.

71. Smith WL, De Witt DL and Garavito RM: Cyclooxygenases: structural, cellular, and molecular biology. Annu Rev Biochem 69: 145-182, 2000.

72. Wang D and Dubois RN: Cyclooxygenase-2: a potential target in breast cancer. Semin Oncol 31: 64-73, 2004.

73. Sotiriou C, Lacroix M, Lagneaux L, Berchem G and Body JJ The aspirin metabolite salicylate inhibits breast cancer cells growth and their synthesis of the osteolytic cytokines interleukins-6 and -11. Anticancer Res 19: 2997-3006, 1999.

74. Planchon P, Veber N, Magnien V, Prevost G, Starzec AB and Israel L: Evidence for separate mechanisms of antiproliferative action of indomethacin and prostaglandin on MCF-7 breast cancer cells. Life Sci 57: 1233-1240, 1995.

75. Noguchi M, Earashi M, Minami M, Miyazaki I, Tanaka M and Sasaki T: Effects of piroxicam and esculetin on the MDA-MB231 human breast cancer cell line. Prostagland Leukotr Essent Fatty Acids 53: 325-329, 1995 